\title{
Republican critics step up pressure on technology assessment office
}

Washington. The US Congress's Office of Technology Assessment (OTA) is edging closer to the brink of closure by Republicans, who have dominated the House of Representatives since last November's elections. Last week Ron Packard (Republican, California), who chairs the House of Representatives appropriations subcommittee that funds the OTA, joined Connie Mack (Republican, Florida), his Senate counterpart, in supporting its elimination.

House Republicans who support the OTA, led by Amo Houghton (Republican, New York), who will chair its management board if it survives, hope to have a meeting with Mack this week to plead for the survival of the \$22-million, 200-strong agency, which assesses science and technology issues for the Congress.

But Mack's staff say he has made up his mind to pursue the closure of the OTA, following the endorsement of that course of action at a closed meeting of the 53 Republicans in the 100-strong Senate last month. They add that at meeting with Packard last Friday, he too supported OTA's closure.

Since its creation in 1972, the OTA has produced several hundred detailed reports for Congress on everything from nuclear proliferation to the state of the US contactlens industry. In doing so, it established the principle that an effective legislature needs its own source of advice on science and technology matters, in order to handle political decisions involving increasing technical complexity. Under the leadership of Jack Gibbons - now President Bill Clinton's science adviser - from 1980 to 1993, the OTA became a model widely imitated in other industrial countries.
Lewis Branscomb of Harvard University, a member of OTA's advisory council, says that scientists and engineers should support the OTA against the current threat. "It took 20 years to build this into a highly trusted agency," he says. "I hope the scientific community will rally behind it as a valuable resource that the country needs."

The advisory council met Houghton and OTA officials in Washington two weeks ago, and advised the officials to collect examples of the OTA's work that would attract the attention of members of Congress who are unfamiliar with it.

But, given the OTA's penchant for detailed and thorough reports that present options without issuing clear-cut recommendations, this may prove a difficult task. A leaflet being circulated by the OTA, for example, shows that it has saved the government $\$ 14$ million a year by saying that a treatment of Alzheimer's disease needed no government regulation; $\$ 368$ million on computers for the social security department; and - fancifully - $\$ 60$ billion on the Synthetic Fuel Corporation, a pet project of Jimmy Carter, the former president.

Robert Walker (Republican, Pennsylvania), who chairs the House Science Committee, has expressed support for a smaller agency that would produce advice in less than the 18 months that OTA takes for its major reports. Roger Herdman, OTA's director, says the agency is ready to speed up and reduce its size.

But Herdman says the agency has already reduced its management by 30 per cent over the past two years, and refuses to accept that it should offer to cut a third of its staff. He says that Congress plans to cut its

\section{How the earthquake struck Japan}

\begin{abstract}
A map prepared by the US Geological Survey (right) shows the major plate boundaries, marked by yellow lines, in the area where the Kobe earthquake struck on 17 January. The map also shows significant earthquakes that have occurred between 1961 and 1994, the size of a dot being proportional to the magnitude of the earthquake, and its colour indicating its depth.

Last week's earthquake, denoted by a star, occurred on a strike-slip fault branching off a larger strikeslip fault known as the Median Tectonic Line. Rupture zones are indicated by red lines. (See also page 273.)
\end{abstract}

support agencies by 10 per cent, and that the OTA should be treated likewise.

Herdman, a 61 -year-old former paediatrician and public health official, joined the OTA as head of health and life sciences in 1983. He succeeded Gibbons last May after some well-known outsiders, including Maxine Singer, president of the Carnegie Institution, turned down the job.

Some of OTA's supporters in Congress say that it has lost its high public profile and some of its best people under Herdman. But he says that a smaller management structure, with seven out of nine division heads newly promoted, means that the agency is maintaining its intellectual edge.

OTA's present troubles began last February when Mack attacked its reports for their lack of focus on technology. In response, Herdman drew up new rules specifying each study's technological content. But a senior member of Mack's staff dismisses this as a "minor managerial change".

Mack feels his concerns were ignored when he was a minority senator; now they cannot be. Hence the recommendation of a task force, chaired by Mack and Senator Pete Domenici (Republican, New Mexico), to close the agency. Ancient grudges - for example over OTA's more partisan early days - are not thought to have played much of a role in the Republican Conference's acceptance of that.

Instead, an agency that does its work for an officer corps of congressional committee heads may be paying a price for its obscurity in the ranks. "If you did a market research study on OTA's efficacy in Congress, the response would be 'OT what?'," says one Republican member of staff. "And it's not bad PR; it is a question of the usefulness of the product. I can't name an OTA study in five years that has played an integral part in legislative activities."

Neil Harl, professor of economics at Iowa State University and chairman until last month of the OTA advisory council, says that the closure of the OTA "would be a tragic outcome". Those fighting to save it will argue that it is uniquely equipped to help frame laws on very complex issues, such as the patenting of the human genome.

But they face an uphill task. The prevalent view in Congress today is that it does not need an exhaustive, peer-reviewed study before deciding to reject unnecessary schemes such as the Synthetic Fuel Corporation. The reports being read in Congress this year emanate from corporate-funded think-tanks such as the Cato Institute: they may lack objectivity - but they come quickly to the point, and free of charge to the taxpayer.

Colin Macilwain 